\title{
A Perfect Storm: The Social and Institutional Contexts of Samoa's 2019- 2020 Measles Epidemic and the Lessons learned for the COVID-19 Pandemic
}

Ramona Boodoosingh, Safua Akeli Ama'ama and Penelope Schoeffel, National University of Samoa, Museum of New Zealand Tepapa Tongarewa

\begin{abstract}
In late 2019 and early 2020, an epidemic of measles ravaged Samoa, and nearly three people in every hundred (2.83\%) in the small population were infected, with 1860 hospitalizations and 83 deaths, mainly children. In the circumstances of the 2020 Covid-19 pandemic, this case study shows that even when a proven vaccine exists for an infectious disease, circumstances may prevent its effective use. As academics and researchers who live and work in Samoa, this article seeks to shed some light into contributing factors to the measles outbreak. These include inadequate data collection, low vaccination coverage, weak institutional capacity, unpreparedness for an epidemic, lack of public information, vaccine hesitancy and anti-vaccine propaganda and public recourse to traditional and 'alternative' therapies. Through a combination of personal observation, analysis of media articles, government reports and historical documents, we present an overview of the circumstances of the measles epidemic. We trace the circumstances of low vaccination coverage, institutional weaknesses and an uninformed public resulting in a delayed an effective response. In conclusion we reflect on the lessons that history offers on public health services in Samoa.
\end{abstract}

Keywords: Measles, Epidemic, Samoa, public health, Covid 19, vaccination

\section{An Underlying Tragedy}

In late 2019 an epidemic of measles ravaged Samoa. In the article we offer an overview of the colliding circumstances underlying the epidemic of measles in which inadequate data collection, low vaccination coverage, weak institutional capacity, unpreparedness for an epidemic, lack of public information and public recourse to traditional and 'alternative' therapies all combined to drive a high infection and mortality rate. As of January $6^{\text {th }} 2020$, there were 5697 reported cases, 1860 hospitalizations and 83 deaths (Lesa 2020). The infection rate was $2.83 \%$ of the estimated population of 200,000 , amounting to nearly three people in every hundred (2.83\%). We also describe how, in less than a year since the epidemic, Samoa has learned from its weaknesses and mistakes and has so far effectively prevented the incursion of Covid-19.

The precursor to the epidemic was a medical misadventure in 2018 when two infants died within minutes of being injected with a deadly mixture of an expired anesthetic, Atracurium, with the Measles, Mumps and Rubella (MMR) vaccine (Dreaver 2019). There was an immediate presumption that the vaccine itself was responsible for the deaths, and it was announced in the press that the vaccine was withdrawn. Two weeks passed before health authorities discovered that the infants had been poisoned; the two nurses involved, realizing their error, had taken the vials home and hidden them. However this was not made public. During the intervening period, there was intense speculation in the media in Samoa and abroad about whether the vaccine itself had caused the deaths. Headlines were attention grabbing, with examples such as:

"Samoa recalls vaccines, orders full investigation after two baby deaths" (Graue and Walsh, 2018) 
With the following leading text:

"Samoa has issued an immediate recall of the vaccine for mumps, measles and rubella (MMR) following the deaths of two infants who reportedly passed away just hours after receiving their shots" (Graue and Walsh, 2018)

Another media release made reference to the New Zealand's Ministry of Health's statement on the tragedy in Samoa (New Zealand Ministry of Health 2018):

"Ministry of Health statement on the investigation into MMR vaccine safety in Samoa"

This was accompanied by the leading text:

"The New Zealand Ministry of Health expresses its condolences to the families of children who recently died in Samoa shortly after the administration of MMR vaccine. Samoan health authorities have launched an investigation into the deaths - until this is complete, it is too early to determine their underlying cause."

The deaths were widely reported in New Zealand, with this example from TV1 News NZ (Dreaver 2018):

"Two babies die in Samoa Hospital minutes after receiving MMR vaccinations, investigations underway"

This was followed with the leading text:

"The Samoa Government has seized the MMR (Mumps, Measles and Rubella) vaccine from around the country and launched an investigation following the deaths of two babies last Friday."

Similarly, concern by international agencies was also widely reported, for example: (World Health Organization and UNICEF 2018):

"World Health Organization and UNICEF Pacific statement on the deaths of two children in Samoa after MMR vaccine"

This was accompanied by the following leading text:

"UNICEF and the WHO are deeply concerned about the deaths of two children in Samoa last week after they received a routine Measles, Mumps and Rubella (MMR) vaccine. The death of these two children is a tragedy and our thoughts and prayers are with their families and the people of Samoa." 
These and other reports planted the suspicion firmly in the minds of the public that the MMR vaccine was the cause of the deaths. Although there was an immediate four-month suspension of the administration of the MMR vaccine and although ten months passed before routine vaccinations resumed, with the public still mostly unaware that there had been a medical misadventure, there was widespread public fear of the MMR vaccine. Several mothers were reported as saying they had lost faith in the public health system they preferred to treat illnesses via traditional means (TautuaFanene 2018). The suspicion that the vaccine was to blame enabled anti-vaccination activists in Samoa and overseas to seize public attention. Media reports in 2019 referred to the activities of

anti-vaccination activists such as Samoan-Australian blogger Taylor Winterstein and Samoan Edwin Tamasese. A workshop was planned by a group of anti-vaccination advocates "Making Informed Decisions" to promote their theories in Samoa in June 2019. Although, the World Health Organization and other scientific experts cautioned against the potentially detrimental effect this would have on public opinion on vaccines, the Ministry of Health's Director General Leausa Dr Take Naseri was reported to have said that they welcomed the opportunity to debate such theories (Mayron 2019a). This was despite evidence that anti-vaccination propaganda can produce vaccine hesitance, mediated by "the perceived dangers of vaccines, and feelings of powerlessness, disillusionment and mistrust in authorities" (Jolley and Douglas 2014). The workshop was eventually cancelled.

The majority of the public became aware of the real cause of the deaths when the case against the nurses went before the courts in August 2018 and was reported in the press (Morrah 2018). The nurses received sentences for manslaughter and for 'obstructing and defeating the course of justice' (Police v Tauvale 2019). In sentencing, the Judge, Vui Nelson referred to the need for local health authorities to refrain from defensiveness but to pay attention to the ethics of their profession and its protocols and standards (Police v Tauvale 2019).

\section{Measles Vaccination Coverage in Samoa}

The second factor was low measles vaccination coverage. Prior to the measles outbreak in 2019 the levels required for 'herd immunity' in Samoa had not been reached for many years. This requires vaccination levels between 93\%-95\% (Funk 2017). Records of the administrations of measles vaccines (MCV) in Samoa date back to 1982, and to 2004 for the vaccine including rubella (MR), (World Health Organisation 2020; McFarland et al 2003). In 2009 the triple vaccine for measles, mumps, and rubella was introduced (Ministry of Health (MOH) and Samoa Bureau of Statistics (SBS) 2015). Since its introduction in 2009, the vaccination coverage rate of the MCV2 has not exceeded 87\% (reached in 2013). Figure 1 shows the coverage of MCV1 and MCV2 from 1982 to 2018. 
Figure 1: Coverage of MCV1 and MCV2 (\%) in Samoa from 1982 to 2017 (World Health Organization, 2020)

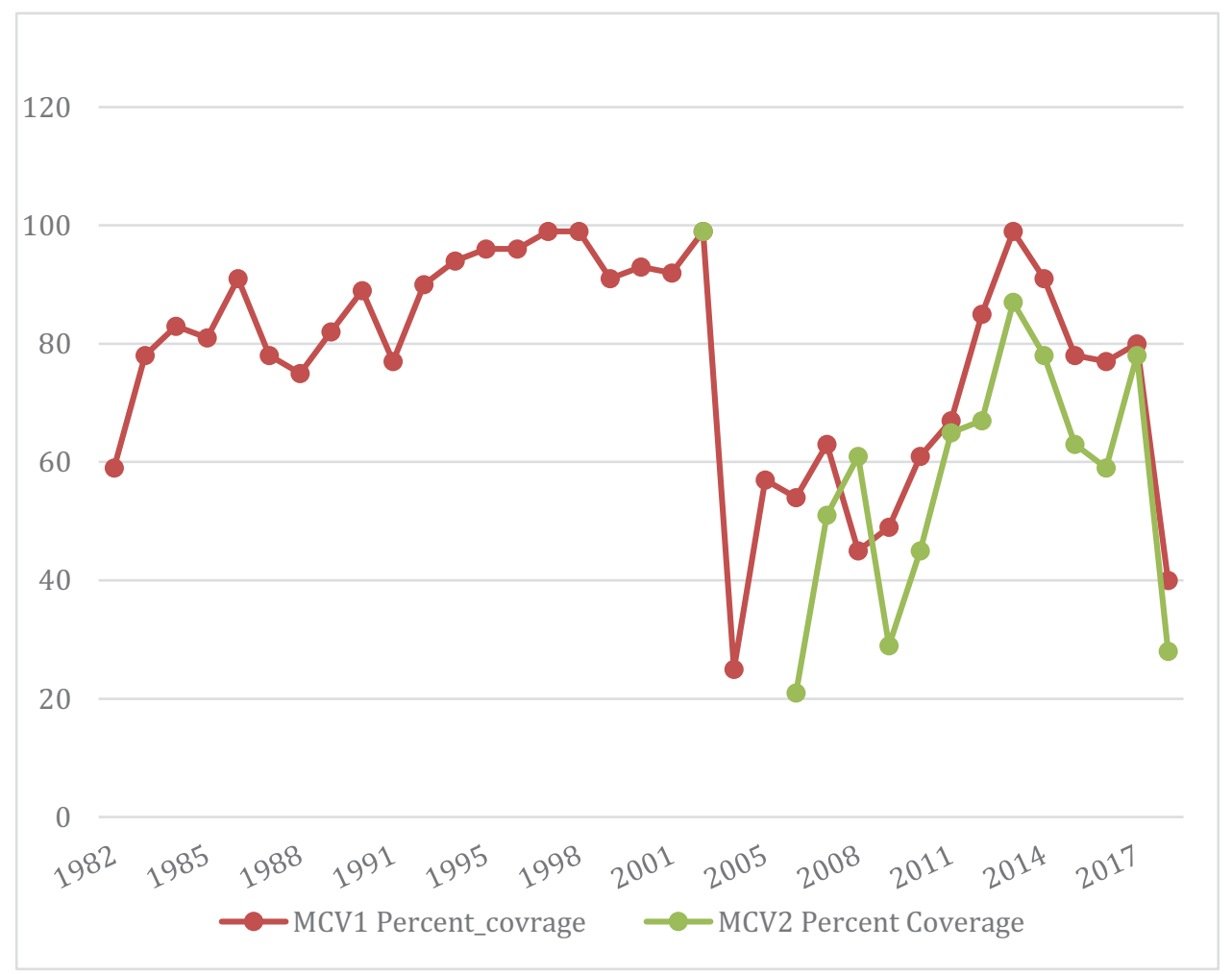

The actual vaccination rate may have actually been lower than the reports indicate because vaccination coverage may have been overestimated. The rates cited by international agencies are derived from the Samoa Demographic Health Survey (SDHS), which is conducted every five years, utilizing a representative statistical sample of the population. Immunization coverage is gauged by the presentation of immunization cards or, in the absence of those, and the mothers' recall of the child's vaccination status ( $\mathrm{MOH}$ and SBS 2015). Relying on recall introduces a potential error if mothers are reluctant to admit they did not have a child vaccinated. The 2014 SDHS captured information on children 18-29 months of age, the youngest age by which they should have received all of their vaccinations (World Health Organisation 2019a). This survey used a nationally representative sample of 4171 households, $16 \%$ in rural areas and $17 \%$ in urban areas $(\mathrm{MOH}$ and SBS 2015). According to the survey, $76.4 \%$ of the children had received the MMR1 (51.3\% based on vaccination cards and $25 \%$ on mothers' reports), and $52.1 \%$ of the children had received the MMR 2 (39.0\% based on presented vaccination cards and $13.2 \%$ based on mothers' recall). Figures from Samoa's four census regions (Figure 2) show that Savai'i, a mainly rural area, had the highest percentage of complete vaccinations (73\%), followed by rural districts of Upolu, the Apia Urban Area, while the lowest rate was in North West Upolu which is the most populous area of Samoa and includes several non-village suburban areas. Sixty two percent of mothers in rural areas were able to produce vaccination cards compared to 56 percent of mothers in urban areas (MOH and SBS 2015). The difference may reflect the weaker system of local government in Samoa's urban areas compared to rural villages, where health center staff are likely to have more knowledge of the local population. Children in the oldest cohort (42-59 months) were less likely to have received all their vaccinations ( 36 percent) than younger children aged 30-41 months (43 percent) and 18-29 months (50 percent) within the prescribed age. This declining trend was also observed in the ability to produce vaccination records, $61 \%$ of children aged $18-29$ months, $56 \%$ of children aged $30-41$ months and $47 \%$ of the oldest children $42-59$ months. According to the data gathered for the SDHS $2014,8 \%$ of children $18-29$ months had not received any vaccinations, compared to $15 \%$ in the SDHS 
2009. Despite this improvement, only $50 \%$ of children aged 18 months had received all basic vaccinations according to the data gathered by the 2014 SDHS (MOH and SBS 2015). In early 2020 during the epidemic, there was a massive push from the government, with external assistance, to raise the vaccination coverage levels to achieve herd immunity. This emergency response vaccination has occurred in other developing countries, for example, in an evaluation of an outbreak of measles in the Democratic Republic of Congo in 2013, Gignoux et al (2018), documented how a similar combination of low vaccination coverage and a reactive vaccination program contributed to eventual coverage rate.

Figure 2: Map of the four population census regions Apia Urban Area AUA), North West Upolu (NWU), Rest of Upolu (ROU) and Savai'i (SBS, 2016)

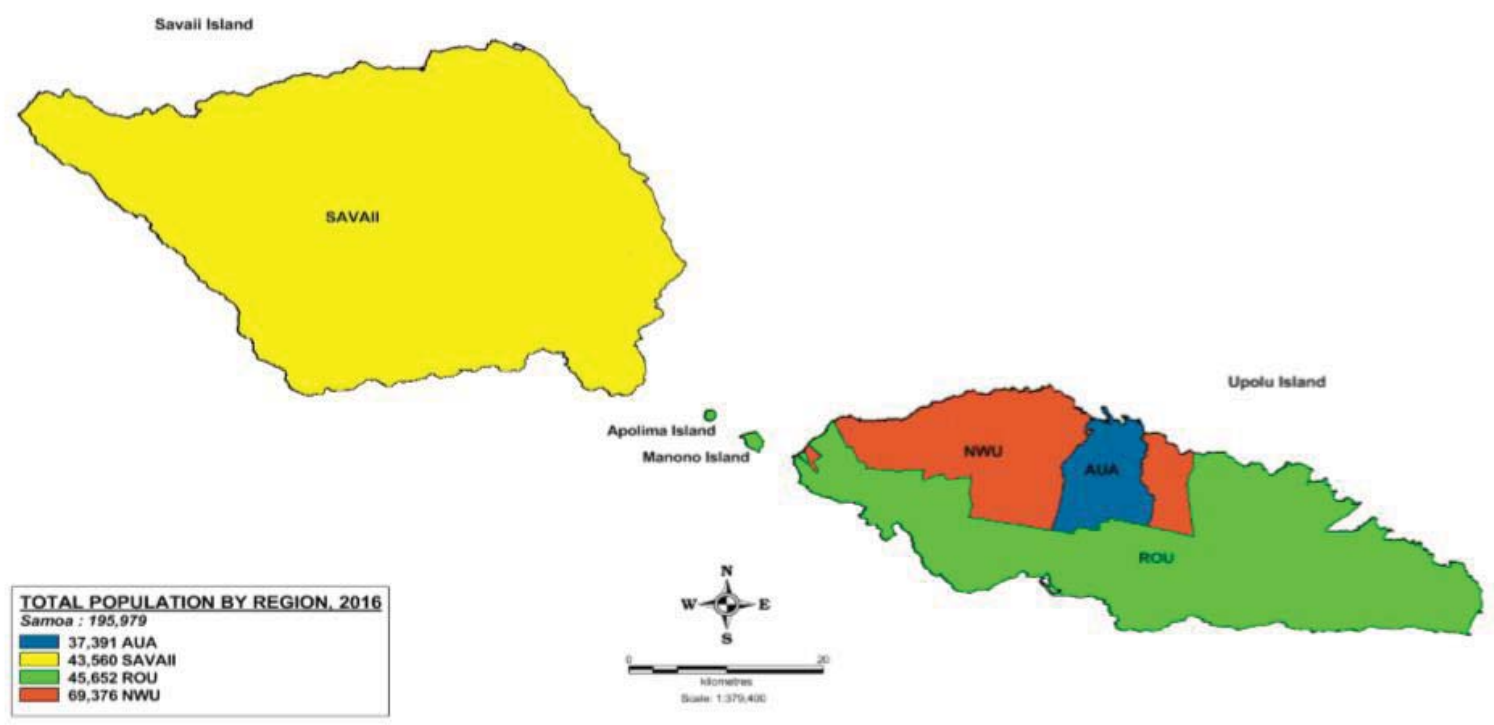

\section{The Measles Epidemic}

The outbreak of measles in Samoa was declared in mid-October and on 15 November a State of Emergency was declared, however the National Emergency Operation Centre was not given the authority until 18 November to manage and organize the response (Mayron 2019 i). It was not until early December that effective action was taken; there was a national lock-down with roads closed to all but essential workers and vaccination teams. These teams included Samoan health workers and members of overseas medical assistance teams, including specialists from New Zealand, Australia, United States, Britain, Japan, Israel and Papua New Guinea.

The source of the outbreak appears to have been New Zealand where there had also been an outbreak, although with less devastating consequences. There are daily flights between Auckland and Samoa, and Samoa has a sizeable diaspora in New Zealand, with most living in the Auckland area. As of September 11th 2019 it was recorded that over 45\% of the measles cases in Auckland were Pasifika (people of Pacific Island ancestry and that most of these cases were in Samoan and Tongan communities (Meyer 2019a). Subsequent statistics published in October 2019 showed that 
Pasifika peoples were seven times more likely to become infected with measles than the general population (Meyer 2019b). Dr Helen Petousis-Harris, based at Auckland University New Zealand claimed that New Zealand was culpable for the "exportation" of measles to Samoa (Meyer 2019c); the immunologist and vaccine specialist at Auckland University said she was furious New Zealand had "exported" measles to Samoa. There were measles outbreaks in New Zealand in 2019 and Ministry of Health data showed that the three Auckland health administrative areas had less than optimal immunization rates in the 70s among Pasifika people.

According to the Samoa Ministry of Health's public information release on October $30^{\text {th }}$ 2019, 314 suspected measles cases with 15 confirmed cases were recorded in Samoa by October $27^{\text {th }}$. Three measles-related deaths were recorded; a 14-month-old; an 8-month-old and a 37-yearold, and were awaiting laboratory confirmation, from New Zealand, due to laboratory weaknesses in Samoa (MOH 2019). The Ministry of Health advised that measles is highly contagious, as follows:

"We wish to remind the public that the measles virus is very contagious. The measles virus can be spread by an infected person through the air through breathing, coughing or sneezing. It is important for the public to remain alert for any signs or symptoms of measles." ( $\mathrm{MOH}$ 2019)

In the following step up of vaccination, there were immunization clinics located at the Tupua Tamasese Meaole Hospital (TTMH) on Upolu and at the Malietoa Tanumafili Hospital on Savai'i $(\mathrm{MOH}, 2019)$ but there were reports in the media of the supply of the vaccines running out in Savai' $i$ and of issues with the lack of cold storage (Sanerivi 2019). Despite these concerning reports, the Ministry of Health did not respond publicly. By the end of the first week of November 2019, the number of suspected cases had increased to 513 and still there were only three vaccination locations. Two locations were at the hospitals in Upolu and Savaii and the third was in the center of the Apia Township (Mayron, 2019b). Overcrowded waiting areas for vaccinations were observed at TTMH in the period leading up to the countrywide shut down for mass vaccinations in December. The fear of potential exposure in a crowded environment while waiting for a vaccine may have dissuaded some parents from bringing children for vaccination (Stein-Zamir et al. 2019).

\section{Institutional weakness and the rapid spread of infections}

The Ministry appears to have been slow to realize the potential magnitude of the outbreak and was slow to declare it and plan for its management. Accordingly the public was unaware of how serious the situation was, which undoubtedly contributed to the rapid spread. Samoa has very few remote or isolated villages; it has a closely interconnected population living on two adjacent islands linked by ferry services, in villages close to or alongside the main roads around the periphery of both Islands. In October 2019, when the outbreak of measles was first identified "White Sunday" was held; an occasion when most churches throughout Samoa gather children and their families together for a special day-long celebration. This would have created an ideal environment for virus transmission. Another factor is transportation. Although many Samoan families own cars or trucks, most people, especially young people, rely on bus services, which in Samoa are privately owned and operated (SBS 2013). As they often run less than three times a day with none on Sundays, buses are very crowded. Lack of reliable, weeklong access to transportation meant that many people were unable to quickly access vaccination services. Within three weeks of the epidemic being declared there were calls for the Ministry of Health to decentralize the vaccination response, so that vaccinators could go to the villages. One woman responding to the Samoa Observer article on public responses to the epidemic said:

"When I went to the hospital, I knew that the Ministry of Health response was late because they said all people should go to the hospital to get an injection for measles. But for me, the 
Ministry of Health should put together a team and send them to the village rollout the vaccination programme because the disease is spreading fast. Some people live far from the hospital and they don't have access to vaccines. The Ministry should dispatch a group of nurses, like what they did when they ran a vaccination programme for women." (Ulutoa, 2019)

There was a revealing incident reported on November 20th 2019, that five days into the state of emergency, about two hundred people were turned away after they had lined up at the Samoa Red Cross building expecting vaccinations to be administered by the Ministry of Health staff (Wilson 2019). In a Government Press release on 23 November 2019, the public was advised that private clinics providing the measles vaccinations for a fee had been closed as inquiries were proceeding, giving the reason that there was "no formal agreement between the clinics and Ministry of Health on operations and safety requirements needed". It was not clear how the vaccines, which could only have been obtained by the government, were made available at the clinics (Government of Samoa 2019b). Only two days later in a Radio New Zealand report, the public was advised that another private clinic, which had provided measles vaccines, had received approval from the previous National Health Services and were awaiting permission to go ahead after a Ministry of Health and UNICEF evaluation (RNZ 2019). Ten facilities besides district health centres were listed as providing vaccinations and treatment for measles (Government of Samoa 2019a) but this information was only made public a few days before the mobile outreach campaign commenced. Until that was carried out most people were expected to travel to health centres on both major islands (Tupufia - Ah Tong 2019a).

Such delays are not unique to developing countries like Samoa; for example, in 2003 the Japanese government withheld World Health Organisation data that SARS symptoms had been recorded in Japan and also did not start a prevention plan in communities, affecting preparedness and facilitating the spread (Gesser-Edelsburg et al 2018). The rapid spread was clearly related to the delay in declaring an outbreak and building public awareness and the confusing response by the Ministry of Health. The response by the Director General of the Ministry of the Health was defensive in tone (Mayron 2019c). This may have been because the government of Samoa exerts tight political control over information from government agencies, which may have deterred the Director General of the Ministry of Health from speaking earlier and more frankly. The same criticisms have been widely made of the government of China concerning suppression of information about the early indications of the Covid-19 virus in Wuhan in January 2020. The lesson here is that public trust in the directives of the government during an epidemic is important and can exist in the presence of low knowledge about the illness, fostering receptiveness to government directives (Deurenberg Yap et al. 2005).Despite advice from the World Health Organisation and UNICEF, Samoa was not prepared for the epidemic. These agencies sent warnings to all Pacific Ministers of health on prevention and outbreak response to the threat of measles, motivated by the re-emergence of measles in New Zealand. One measure that should have been taken immediately was surveillance at the Auckland airport and at the Faleolo international airport in Samoa. However no measures were taken to stop the spread of infection to the islands. In contrast, an appropriate measure was taken by the authorities in American Samoa, which prevented the spread of measles from Samoa by banning travelers unless they presented proof of vaccination against measles at least two weeks prior to travel.

Another factor underlying the problematic response by the government to the epidemic was the upheaval in the management of the health sector. In an organizational reform in 2006, responsibility had been divided between two agencies, the National Health Service and the Ministry of Health, each with its own director, apparently on the advice of international consultants. In 2019, under the NHS Amendment Bill (2018), the NHS and MOH were merged again. Issues of rising expenditure on personnel and decline in the provision of services were rumored as reasons, as was 
neglect of community health programmes, which had tended to focus on cancer and STIs but less upon other common infectious diseases. This may reflect the focus of international agencies funding health programmes in Samoa.

\section{Knowledge, Samoan Culture and Social Factors}

Measles is often believed to be a harmless childhood infection, but in fact the disease carries the risk of severe complications, including "encephalitis, severe diarrhea potentially leading to dehydration, ear infections and severe respiratory infections such as pneumonia ... which is the cause of the majority of measles related deaths ..." (World Health Organisation 2019b). It was evident that most health workers and members of the public had never seen the condition before. Most people did not know what its symptoms were, or that the disease was very infectious. This is because measles is now rare in comparatively rich countries like New Zealand and Australia and has not been a public health concern for many years, due to effective mass vaccination in those countries.

Traditional medicine is still widely practiced in Samoa, incorporating massage, herbal infusions and other measures for the removal of harmful supernatural causes of illness. Many Samoans believe that there are two types of illnesses; Samoan illnesses (ma'i Samoa) and foreign illnesses (ma'i palagi). The former are amendable to Samoan treatments, the latter to medical treatment from the hospital or medical center (see MacPherson and MacPherson 1990). For example, a common 'Samoan' illness termed mūmū (of which there are many types), may manifest itself with fever or a rash. It is likely that many Samoan parents assumed that those with the symptoms of measles had mūmū and took them to a traditional healer (föfō or taulāsea). An immediate public health measure should have been to alert traditional healers about measles and the need for vaccinations and medical treatments. When a person becomes ill families and individuals often oscillate anxiously between the hospital or clinic and the traditional practitioner, looking for speedy results. A child might be taken out of hospital if the parents are not satisfied with the treatment, or if recourse to a traditional healer has been unsatisfactory, a child may be taken to the hospital (Schoeffel 2016).

There appears to have been uncertainty among health workers about what to do when a person presented with symptoms of fever, sniffles and sore eyes. Several media reports tell of children being sent home with medication for fever. In one such case, a mother turned to traditional healers after attempting to seek assistance from the health facilities; the mother subsequently returned with the child to the health facility as his condition worsened and the child died (Tupufia Ah Tong 2019a). In another, a seven-month-old with fever and refusal to feed was turned away five times until she was admitted to the hospital for treatment for measles; the mother reported that she was called a "paranoid mum" (Jackson and Lyons 2019). In another report a child who was twice incorrectly diagnosed with common cold by doctors, later died from complications of measles. The child had not yet received the first MMR vaccine, having missed the appointment after the suspension of the MMR vaccination program in 2018 (Mayron 2019d). Another child, known to one of the authors, was in remission from cancer and was called to the hospital for a checkup; being immune suppressed, he caught measles and died about a week later. Severe shortages of health workers, essential equipment and the absence of briefing of health workers on Samoa's measles treatment protocol were revealed in a newspaper report detailing the TTM hospital's weaknesses in the response to the measles outbreak in February (Mayron 2020).

In addition to traditional medicine, from time to time there are fashions for 'alternative' treatments. At the time of the measles epidemic in Samoa, one of these was 'Kangen water' (alkaline water, with acidity removed by a device) and a number of highly placed people in Samoa advocated its use to maintain good health. There is one report of a parent taking a child of four years of age with measles signs and symptoms to get the Kangen Water from an alternative healer. The mother 
indicated fatalistic religious beliefs, saying that she believed her child's "fate was preordained" (Fruean 2019a).

In November 2019, despite the Director General of the Ministry of Health indicating that the public should seek assistance from a medical provider when measles symptoms develop, Kangen Water continued to be made available to the public. One of the alternative healers, who claimed it could cure measles, was eventually ordered by the Ministry of Health to desist, with police intervention. A leading local anti-vaccination activist was recommending that children with measles could be treated at home with Vitamin $A$ and $C$ and liquid zinc, which was being sent to him by other anti-vaccination activists in the United States, and which he and his family were distributing (Mayron 2019e). On 22 November the police issued a public warning to anti-vaccination advocates and this was announced in the media more than one month after the outbreak had been declared (Mayron 2019f). Edwin Tamasese, a prominent local anti-vaccination advocate and self-proclaimed healer used vitamins and natural plants in his treatments, ignored warnings and was arrested on December $5^{\text {th }} 2019$ and charged with incitement against the Samoan Government's vaccination order, after making the following statements on Facebook:

"I'll be here to mop up your mess. Enjoy your killing spree" (Kerr 2019)

The case was seen in the District Court on December $10^{\text {th }}$ where he stated that he was not guilty, he was released on bail until a new hearing is scheduled (Vai 2019). Tamasese faces a sentence of up to two years if found guilty for this offence.

\section{Communication Issues}

Until the overseas medical support teams arrived the health services in Samoa were overwhelmed, with a lack of clear guidelines, procedures and communication strategy. School closures which commenced two weeks after the declaration of the outbreak on October 16, were poorly communicated to the public, with parents and preschool teachers in the Apia area saying they did not know about the instructions from the Ministry of Health to keep children under the age of five years of age at home (Mayron 2019g).

Around the world it has become common for people to search online for additional information about health issues, especially when this is not provided openly and accessibly by the health organizations. Clear information and instructions about what to do from official sources is essential to avoid confusion, panic and the spread of false information (Gesser-Edelsburg et al 2018, French 2011, Mayron 2019h). In Samoa's measles epidemic the Director General of the Ministry of Health and the Prime Minister were in charge of the outbreak response under the National Emergency Operation Centre (N.E.O.C), with responsibility for actions that were taken and not taken (French 2011). Although the outbreak was declared in mid-October and the State of Emergency on 15 November, the National Emergency Operation Centre was not given the authority until 18 November to manage and organize the response (Mayron 2019i). However, these leaders have refused to accept calls for a formal enquiry into the epidemic, seeing such suggestions as political finger pointing. As commented in the local press:

"The prime minister has shut down criticism of his government's handling of the crisis, saying that those who have suggested an inquiry into the outbreak show a lack of "common sense" and that such calls were a "political gimmick". (Jackson and Lyons 2019) 
Requests for an inquiry into the Government response to the measles outbreak were rejected by the Prime Minister, positioning the call as a political tool (Tupufia - Ah Tong 2019c). At times the Prime Minister placed the blame for infection and deaths among children on their parents, and in particular on mothers who had not vaccinated their children (Tupufia - Ah Tong 2019b). This was despite lack of government action on low vaccination rates for many years prior to the outbreak, a failure to respond to warnings by World Health Organisation and UNICEF, and the suspension of vaccination in 2018. The local media quoted a British journalist, who said that the Prime Minister was "evasive" about the epidemic. This journalist was one whose reporting had led to the retraction of the Lancet article linking vaccination with a risk of developing autism (Fruean 2019b). To date, Samoa's government has avoided a public call for a national inquiry into the measles crisis. This has very serious implications for the country at multiple levels, including the role of the National Human Rights Institute. The effectiveness of the leadership during a public health crisis includes having an elected official 'who is prepared to take responsibility for the crises response outcomes' (French 2011 reviewing Khan, 2009) and in this regard, the Samoan government failed. A review of the crisis should be prioritized in order to evaluate key areas of the health system and provide a comprehensive understanding of health reforms for the long-term benefit of society. In doing so, taking lessons from past events will be crucial in how the State will manage health and illness, and rebuild public trust in the Ministry of Health and rebuilding the system of community engagement that once worked so well.

Over time Samoa has shifted its public health focus to the management of noncommunicable diseases (NCDs) (See Lameko, this volume). While most mortality in Samoa is due to NCDs and makes sense in a stable environment, it can potentially limit the agility of the system to respond in times of public health crisis. As Razzaki and Kellerman (2002) contend:

Historically, global health policy emphasized multiple, vertically oriented programmes that concentrated on maternal and child health and the control of communicable childhood diseases. This resulted in major public health agencies focusing their support on selective programmes that address priority diseases and activities. Unfortunately, vertical programmes do not encourage the development of strong and efficient health care delivery systems. The weakness of this approach is most apparent during crises, such as medical emergencies or incidents involving large numbers of casualties.

Less than $20 \%$ of the beds according to the Samoa National Health Service 2017/2018 annual report (12\% TTM and $18 \%$ at Savai'i's major hospital) were dedicated to a combination of emergency, outpatient or communicable disease control. The bed capacity at all other district facilities is 15 or less for a total of 80 beds across all eight locations. Thus, $42 \%$ of the total number of referred cases seen at the Emergency Department at TTM were from district health facilities, an indicator that the district health facilities were already unable to respond at the time of the measles outbreak.

\section{Lessons from History}

Samoa is uniquely well situated, with its accessible and mainly well-organized communities, to disseminate public health information that encourages healthy practices. Unfortunately the system it had in the past for this purpose was almost completely discontinued by 2019. The reemergence of measles in New Zealand and its spread to Samoa occurred when the authorities ignored history and the responses to and consequences of earlier measles epidemics. 
Samoans had been exposed to measles a number of times in the preceding century. As early as 1884, New Zealand vessels such as the S. S. Wairarapa were refused permission to land in Samoa and Tonga due to measles onboard the ship (Evening Post, 1884). However, by the early 1890s, measles had struck rapidly in Samoa with about 200 deaths (New Zealand Herald, 1893) and reportedly 500 deaths in Tonga (Marlborough Express, 1893). A year later, missionary Samuel Hickman Davies (1841-1917) of the London Missionary Society, who had been based in Samoa since 1867 recorded the following observation:

Until a few months ago measles had not entered this group. It was conveyed to Tonga, 500 miles south of us, by the New Zealand steamer Upolu in June last, and from accounts we have received it nearly decimated that group. The same steamer brought the contagion to our group. Here, as in Tonga, the epidemic was at first mild. Comparatively few died in Samoa during the period of the fever and rash. The sequelae and complications have caused the mortality. I have not been able to obtain accurate statistics of the deaths from this recent epidemic throughout Samoa, as the ten inhabited islands of this tropical and volcanic group lie between five parallels of longitude, or, with the intervening straits, cover nearly 270 miles; but, judging from the accurate returns obtained here, including a fifth of Samoa, and also from reports obtained from missionaries and others, no fewer than 1,000 of the entire population of 34,500 died from measles up to the end of December, 1893, and nearly half of these adults. Since then there have probably been a few hundreds more. (British Medical Journal, 19 May 1894, vol. 1, p. 1077).

In 1903, doctors from Sydney had travelled to Fiji to provide support to the Board of Health due to a measles outbreak (Australia Press, 1903). Eight years later, another measles outbreak in 1911, affected populations in German and American Samoa with the mortality in the latter islands about 10\% of the population (Medical Record 1911) and for German Samoa a 'great loss of life'.

New Zealand's very modestly funded administration (1914-1961) placed substantial emphasis on improving public health though a community-based public health system. Legislation (New Zealand Health Act 1920 and the Samoa Act 1921): contained provisions to build an accessible medical service and secondly, and to develop preventive and educational work. This was, no doubt, in response to the Administration's culpability in failing to quarantine Samoa from the 1918-1919 pneumonic influenza pandemic, which killed one in five inhabitants, the greatest proportional mortality of any country or territory in the world (Tomkins 1992). Chastened, the Administration set out to eliminate common communicable diseases, including hookworm, filariasis, yaws, scabies and leprosy. Aiming to promote hygienic practices to prevent these diseases, village women's committees were established. Hygiene committees (komiti tumama hereafter komiti) in the opinion of Lambert, a public health expert in 1929 were "a brilliant illustration of the possibilities of preventive medicine" (Thomas 2001 citing Lambert 1928:3).

New Zealand's public health response was stalled in some districts of Samoa by the proindependence Mau movement; in 1936 a whooping cough and measles outbreak resulted in the deaths of about 300 people, and three main villages had been placed under quarantine (Northern Advocate, 1936). In combatting the spread, the work of the Women's Committees had been praised by government officials:

At the $31^{\text {st }}$ March 1937, there were women's committees in 122 villages, and they have all rendered excellent service, particularly during the outbreaks of whooping cough and measles. In this connection it was observed that the death rate was higher in these villages, which did not possess women's committees (AJHR 1937: 23). 
Only two years later, in 1938, the New Zealand Governor-General Viscount Galway's September visit to the Pacific islands was interrupted due to a measles outbreak (Press 1938), since the Matua, a New Zealand vessel, had introduced measles into the Cook Islands. However, earlier in July, the HMS Achilles had on board three cases, and the Minister of Defence was keen to prevent spread to 'islanders who have little resistance to infection' (Auckland Star 1938).

In the 1930s a number of Samoan doctors (graduates from the Fiji School of Medicine) and local trained public health nurses set out to increase the numbers of komiti throughout Samoa. By the 1940s, the komiti became part of the village governance structure, with the wives of the highestranking matai (chiefs) taking the leadership roles. They were responsible for reducing risks of infectious disease by improving the safety of water supply, village and household sanitation and family hygiene. An important task of each komiti was to conduct regular inspections, often with the district nurse, to make sure that there were no breeding places for mosquitoes and other disease vectors in the village, and to ensure that every household had hygienic standards of living with mosquito nets, clean sleeping mats, and washing facilities and every village had communal toilets (in the early days built on jetties over the sea). They supervised the village bathing pool and drinking water sources (some villages still have komiti houses beside the village bathing pool). They organized monthly clinics for mothers of babies and young children, led by visiting public health nurses, who gave health talks every month on house to keep families health and to reinforce rules about village hygiene. In many villages, the komiti had first aid boxes and provided first aid services for minor illnesses and injuries. These organizations also had a certain amount of authority in local governance matters related to community health, for example, the komiti could fine women who failed to bring their children for monthly health checks. Many komiti also managed community water and sanitation projects related to public health improvement. In the 1960s they implemented Samoa's first mass drug administration for filariasis.

By the 1970s some key public health practices such as village inspections had become somewhat ritualized into displays of new household property (Schoeffel 1984). Thomas $(1986,2001)$ was doubtful that Samoan custom could be blended into effective public health processes due to its hierarchical system; however her observations may reflect the declining priority given to the komiti as an instrument of public health in Samoa's health system. In 1975, responsibility for komiti was transferred from the public health nursing division to a Women's Advisory Committee. In the same year, following the UN International Year for Women, the focus shifted from village health to women and development. In 1982 the WAC became a minor adjunct of the national committee of village mayors (Komiti o Pulenu'u). Concerns and project proposal from komiti had to be channeled to government and donors through the village mayor.

The institutional arrangements linking the komiti to the central government have changed several times until the Women's Division of the Ministry of Women Community and Social Development was established in 1991. The women's committees were de-linked from the public health nursing services in the Ministry of Health because nurses no longer went out to villages routinely; instead people in villages sought advice and treatment from the nearest health center or district hospital, or if they had the means to do so, went to the outpatient clinics at the main hospitals on Upolu and Savai'i. Accordingly, the role of the komiti in community health promotion has almost disappeared. By the late 1980s the health inspectorate (mainly employing young men) took over responsibility for the condition of water supply and village sanitation, so in many villages the komiti no longer considered this work their responsibility for which they, unlike the health inspectors, were not paid. Most villages still have komiti tasked with 'cleaning and beautifying the village'. It should be noted that 'cleaning' in this context means organizing grass cutting and sweeping up litter. Village councils still required all households to maintain the side of their property facing the road; to keep the grass cut and to plant decorative hedges and gardens. However less 
attention is paid to the back of houses, out of sight, where refuse can collect water, providing breeding places for the Aedes mosquito that carries filariasis, dengue fever, chikungunya and zika virus, and discarded coconut shells and food scraps that can attract rats. Chickens and dogs wander largely unchecked in and out of cooking houses at the back of main dwelling houses -- also potential sources of disease. In a small survey of eight village komiti which was investigating knowledge, attitudes and practice on feeding babies and under-five year children (Magbity et. al. 2016) many women said they thought poor hygiene in households was the cause of malnutrition (presumably from diarrhea) among young children. Village women's organizations are nowadays more churchfocused than in the past with many weekly activities including cleaning and decorating and fundraising for the church. There is no longer any direct community-based mechanism under the Ministry of Health for communicating health information.

Since the 1980s, broadly stated, there has been a gradual shift of emphasis from prevention to treatment of illness. Services which once aimed to provide health education and prevent infectious diseases are now geared towards treatment of illnesses, especially non-communicable diseases such as diabetes, cancers and cardiovascular disease which account for most morbidity and mortality in older age groups in Samoa today.

\section{Taking those Lessons Forward*}

Samoa remains one of the few countries in the world with no confirmed cases of Covid 19, a pandemic which has affected millions and killed thousands across the world. Developing countries have been identified as being extremely vulnerable to the impact of Covid 19 due to limited testing capabilities and weak health systems. The vulnerability of Samoa to an outbreak was most evident after the devastating impact of the measles outbreak in 2019 and the lessons learned from it have not been forgotten. Samoa implemented a sweeping series of restrictions in travel, improved health education about Covid 19 and a state of emergency swiftly. By these means, a country which still does not have testing capabilities and which has limited health resources has been able to prevent Covid 19 reaching its shores.

When media coverage of the cases of Covid 19 in Wuhan, China grew in January 2020, few countries put in place any restrictions on entry. On January 23 , with immediate effect, the Government of Samoa put in place requirements for entry into the country including completion of a health declaration, a medical examination within 3 days of travel, 14 days quarantine at last port in a country with no cases of Covid 19 if travelling from a country with confirmed cases of Covid 19 and if the person arrived within the 14 days, quarantine would be applied and if necessary deportation (Government of Samoa 2020a). By January 29, nine travelers who had arrived in Samoa were returned on flights, some who had flu like symptoms and had come from USA and Chinese nationals who had come from China via Fiji (Government of Samoa 2020b). The requirement for a medical certificate was also expanded to include travelers whose transition period was 24 hours or more in a country where there were confirmed cases. The Government press releases included the

\footnotetext{
* The review of the response to an outbreak can provide valuable lessons for health and governance leadership moving forward, to prevent and to be able to respond appropriately to outbreaks in future instances. After the outbreak of Measles in Auckland and its environs in 2019 that preceded the outbreak in Samoa, an inquiry into the response was commissioned. Many of the recommendations that emerged from that review align with the lessons learned from the measles outbreak in Samoa, according to the authors of this paper. These include the need to raise immunization rates to prevent outbreaks, improve documentation of the vaccines administered and bolstering coordination and leadership and the expected functions of those charged with leading the response. The overall conclusion from the Sonder and Ryan (2020) was that the response in New Zealand" followed the outbreak, instead of getting ahead of the outbreak", similar to the findings of the authors of this paper. The full report is available at the link below.
} 
list of countries and the list was updated frequently. There were some instances of public displeasure and human rights concerns with these decisions but the Government of Samoa remained firm, in its decision including Samoan Citizens and Permanent Residents in the requirement for medical clearance and quarantine (Jackson 2020). Requirements were further restricted by mid - March to require a negative test for Covid 19 (as a part of the medical clearance done five days before travel) to be allowed to board the aircraft.

In the reporting of statistics of cases of Covid 19 by country, the cruise ship Diamond Princess is reported as a standalone entity. After one person who disembarked in Hong Kong was diagnosed with Covid-19, the ship was quarantined off the coast of Japan from early February for a month. Over that time 700 more people were infected with the virus. Since that time, several other cruise ships have experienced similar predicaments, with cases of Covid-19 on board and difficulty in finding a port willing to accept them. Samoa's Government banned arriving cruise ships with effect on February 24 (Government of Samoa 2020c), earlier than many other countries. To further reduce the number of people entering the country, the decision was made to reduce the number of flights entering and leaving the country, with effect on March 2nd (Loh 2020). For a country which relies heavily on tourism income and still reeling from the economic impact post the measles epidemic, this was evidence of placing the risk to human health above economic loss.

Samoa closed its borders on March 26 to international flights and the country was put into a two week state of emergency. This was subsequently extended by four weeks for a six week period. In the detailed State of Emergency guidelines, schools were closed, limits to five people for public gatherings, restaurants were only allowed takeaway services, ferry services between the two islands would be suspended for passengers, and people above 60 years were advised to remain at home. It also explicitly stated that church services were banned. Within one week of the State of Emergency, amendments were made in response to reports of churches holding services and social gatherings taking place. These included fines or jail sentences for contravening the requirements (Government of Samoa 2020d). Although personal stories are still shared of church members meeting in the pastors houses for smaller services, the large services which were a fixture are no longer taking place. Another aspect of the SOE regulations included the cessation of bus service, an identified potential contributor of the spread of the measles outbreak.

Most significantly, the weakness in public knowledge of how disease was spread and the availability of information to the public was addressed in the government's response. Educational material is shared through television, radio and via the government's Facebook and Ministry of Health's Facebook pages on how the disease spread and preventative measures. All are in Samoan and English and on Facebook include the use of simple pictures and figures to relay the message. The Government met with all of the village representatives and komiti representatives to discuss and relay information on Covid 19. One the author's students relayed that no children are being allowed to leave the village due to concerns about Covid-19. The Government also addressed quickly the potential issue of misinformation regarding Covid-19 via Facebook messaging, a critical lesson after anti vaccination activists were able to spread misinformation via these social media platforms during the measles outbreak. The Government of Samoa continues to post releases on its Facebook page and other media platforms (television and radio) about the number of tests which have been sent to New Zealand for analysis, awaiting transport and results. Currently Samoa is permitting repatriation of Samoans citizens and permanent residents, subject to strict supervised fourteen-day quarantine on arrival and testing before quarantine ends. 


\section{Conclusion}

Samoa's measles epidemic was the 'perfect storm'; a medical misadventure reducing the already low vaccination rate and opened the country to measles, likely brought in by Samoans from New Zealand. It illustrates the globalized nature of Samoan society and the interlinked world they live in, through its transnational diaspora, population mobility, access to social media such as Facebook, foreign aid dependency, and international affiliation though United Nations agencies. Continuing dysfunction in the health system led to a belated and confused response to the early outbreak, so that as the infection spread and deaths mounted, many among the bewildered and fearful public had recourse to ineffective traditional and 'alternative' treatments. There is also a deeper message from these events; the modernization of health services has not served Samoa well as it moved from a largely preventative focus in services to a largely curative focus. Samoa has a double burden of communicable and non-communicable disease, and in recent years the health system has become dominated by concerns for the health consequences of the latter; diabetes, cardiovascular disease and cancers. The old health system was shaped by the colonial response to the 1918-1919 influenza epidemic with a major emphasis in community health, a system now largely abandoned as professionalization, medicalization, and new hospitals took center stage. As history shows, small populations in islands with limited resources are particularly vulnerable to outbreaks of infectious diseases. Samoa was ill served in an epidemic by its geography. Its population is concentrated in adjacent villages on two main and closely located islands, unlike most other Pacific island states where about half of the population is dispersed in outer islands and other remote areas where it is easier to contain the spread of infection. However, this geography was once a boom to a community based service, and one lesson of the epidemic is that it should now be re-invigorated. The recent response of the Samoan government to Covid-19 illustrates that lessons have been learned and hopefully, that attention will now return to community health and strengthening prevention measures. Today about $60 \%$ of the population in Samoa no longer live under the authority of traditional village councils (Tauaa and Schoeffel 2019), suggesting the need for innovation and an expanded response to community health.

\section{References}

Appendix to the Journals of the House of Representatives (AJHR). 1937. Session 1, A-04, p.23 Auckland Star. 1938. "Measles in Samoa." Auckland Star, vol. 69, issue 184, 6 August.

British Medical Journal. 1894. "Epidemic measles at Samoa." British Medical Journal, vol. 1 (1742), p. 1077.

Deurenberg-Yap, M., L.L., Foo, Y.Y., Low, S.P., Chan, K. Vijaya, and M. Lee. 2005. "The Singaporean response to the SARS outbreak: knowledge sufficiency versus public trust." Health Promotion International, 20(4): 320-326. doi:10.1093/heapro/dai010.

Dreaver, B. 2018. "Two babies die in Samoa Hospital minutes after receiving MMR vaccinations, investigations underway." TV1 News NZ, 10 July. https://www.tvnz.co.nz/one-news/world/two-babies-die-in-samoa-hospital-minutes-afterreceiving-mmr-vaccinations-investigation-underway (accessed 1 May 2020).

Dreaver, B. 2019. "Nurses sentenced to five years in prison for incorrectly administering MMR vaccine that led to deaths of two infants in Samoa." One News, 2 August. https://www.tvnz.co.nz/onenews/world/nurses-sentenced-five-years-in-prison-incorrectly-administering-mmr-vaccineled-deaths-two-infants-samoa (accessed 9 February 2020).

French, P. Edward. 2011. "Book Review Effective Leadership in Times of Public Health Crises, Laura H. Kahn, Who's in Charge? Leadership during Epidemics, Bioterror Attacks, and Other Public Health Crises (Santa Barbara, CA: Praeger Security International, 2009 ISBN: 9780275994853". Public Administration Review, 485 - 487.

Fruean, A. 2019a. "Alternative cures' driving measles danger." Samoa Observer. 16 November. 
https://www.samoaobserver.ws/category/samoa/53373 (accessed 1 May 2020).

Fruean, A. 2019b. "Journalist says Tuilaepa 'evasive' after heated exchange." Samoa Observer. 6 December. https://www.samoaobserver.ws/category/article/54413 (accessed 1 May 2020)

Funk, S. 2017. "Critical immunity thresholds for measles elimination."

https://www.who.int/immunization/sage/meetings/2017/october/2. target immunity leve Is FUNK.pdf. (accessed 29 February 2020).

Gesser-Edelsburg, A., Diamant, A., Hijazi R., and Mesch, G.S. 2018. "Correcting misinformation by health organizations during measles outbreaks: A controlled experiment." PLOS ONE, 1(23). https://journals.plos.org/plosone/article?id=10.1371/journal.pone.0209505 (accessed 10, March 2020).

Etienne, G., Polonsky, J., Ciglenecki, I., Bichet, M., Coldiron, M., Lwiyo, E.T., Akonda, I., Serafini, M., and Porten, K. 2018. "Risk factors for measles mortality and the importance of decentralized case management during an unusually large measles epidemic in eastern Democratic Republic of Congo in 2013." PLOS ONE, 13(3). https://journals.plos.org/plosone/article?id=10.1371/journal.pone.0194276 (accessed 20 March 2020).

Evening Post.1884. "Measles on Board." Evening Post, vol.27, issue 154, 30 June.

Government of Samoa. 2019a. "Ministry's official measles advice." Samoa Observer. 20 November, p. 11.

Government of Samoa. 2019b. "MOH shuts down Private Clinic providing measles vaccination." 23 November 2019.

https://www.facebook.com/samoagovt/posts/moh-shuts-down-private-clinic-providingmeasles-vaccination-govt-press-secretari/2769117296452608/ (accessed 5 January 2020).

Government of Samoa. 2020a. "Health Travel Advisory and Restrictions in Relation to the 2019 Novel Coronavirus (2019-nCoV)." 23 January 2020.

https://www.facebook.com/samoagovt/posts/health-travel-advisory-restrictions-inrelation-to-the-2019-novel-coronavirus-20/2910303915667278/ (accessed 2 February 2020).

Government of Samoa. 2020b."Coronavirus watch - 3 more travelers denied entry." 29 January, 2020. https://www.facebook.com/samoagovt/posts/2922745511089785 (accessed 20 April 2020).

Government of Samoa. 2020c. "Health Travel Advisory Novel Coronavirus (Covid- 2019) Effective Immediately." 25 February, 2020.

www.samoagovt.ws/2020/02/health-travel-advisory-novel-coronavirus-covid-2019effective-immediately-3/ (accessed 20 April 2020).

Government of Samoa. 2020d). “Amended State of Emergency Orders for Coronavirus (Covid- 19) $9^{\text {th }}$ April 2020". 9 April 2020.

http://www.samoagovt.ws/2020/04/amended-state-of-emergency-orders-for-coronaviruscovid-19-7-9th-april-2020/ (accessed 20 April 2020).

Government of Tokelau. 2019. "Tokelau measures and border control against Measles epidemic." November 19, 2019.

https://www.tokelau.org.nz/Bulletin/November+2019/Tokelau+measures+and+border+cont rol+against+Measles+epidemic.html (accessed 30 December 2019).

Graue, Catherine and Michael Walsh. 2018. "Samoa recalls vaccines, orders full investigation after two baby deaths for Pacific Beat." ABC News. 10 July.

https://www.abc.net.au/news/2018-07-10/samoa-recalls-vaccines-order-investigationafter-baby-deaths/9971368 (accessed 26 December 2019).

Jackson, Lagipoiva Cherelle. 2020. "Samoa turns away eight of its own citizens over coronavirus fears." The Guardian, 13 February.

https://www.theguardian.com/world/2020/feb/13/samoa-turns-away-eight-of-its-owncitizens-over-coronavirus-fears (accessed 15 March 2020). 
Jackson, Lagipoiva Cherelle and Kate Lyons. 2019. "These babies should not have died': How the measles outbreak took hold in Samoa." The Guardian, 17 December.

https://www.theguardian.com/world/2019/dec/18/these-babies-should-not-have-diedhow-the-measles-outbreak-took-hold-in-samoa (accessed 30 December 2019).

Jolley, Daniel and Karen M. Douglas.2014. "The Effects of Anti-Vaccine Conspiracy Theories on Vaccination Intentions." PLOS ONE, 9(2): 1-9.

Kerr, Florence. 2019. "Samoa measles outbreak: Edwin Tamasese first anti-vaxxer." Stuff.co.NZ, 6 December.

https://www.stuff.co.nz/world/south-pacific/117918981/samoa-measles-outbreak-edwintamasese-first-antivaxxer-arrested (accessed 23 December 2019).

Lesa, Mata'afa Keni. 2020. "Measles epidemic claims two more lives, death toll 83." Samoa Observer, 6 January.

https://www.samoaobserver.ws/category/samoa/55641 (accessed 20 January 2020).

Loh, Chris. 2020. "Samoan Government Orders Major Flight Reductions To Apia." Simple Flying, 2 March.

https://simpleflying.com/samoan-government-apia-reductions/ (accessed 14 March 2020).

Macpherson, C., and Macpherson, L. 1990. Samoan Medical Belief and Practice. Auckland University Press.

Magbity, M. H., Temese, V., Sa'u, A., Akeli, S., Schoeffel, P., and Sahib, M. 2016. "Infant Feeding in Sāmoa: Knowledge, Attitudes and Practices." Journal of Samoan Studies, 6: 5-20.

Marlborough Express. 1893. "Great mortality from measles." Marlborough Express, vol. 29, issue 219, 6 September.

Mayron, S. 2019a. "Planned Apia anti-vaccine workshop worries Ministry, WHO." Samoa Observer, 2 April.

https://www.samoaobserver.ws/category/samoa/39706 (accessed 27 November 2019).

Mayron, S. 2019b. "Measles cases increase." Samoa Observer. 8 November, p. 1-2.

Mayron, S. 2019c. "Samoa defends long wait on measles admission." Samoa Observer, 15 November.

https://www.samoaobserver.ws/category/samoa/53308 (accessed 5 December 2019).

Mayron, S. 2019d. "Parents remember a boy lost to an epidemic." Samoa Observer, 6 November. https://www.samoaobserver.ws/category/article/52826 (accessed 5 December 2019).

Mayron, S. 2019e. "Top doctor warns of 'conning' campaign." Samoa Observer, 21 November. https://www.samoaobserver.ws/category/article/53464 (accessed 10 December 2019).

Mayron, S. 2019f. "Unvaccinated or unsure pregnant women to stop work, Police warn antivaxxers." Samoa Observer, November 22.

https://www.samoaobserver.ws/category/samoa/53673 (accessed 10 December 2019).

Mayron, S. 2019g. "Parents unaware of last minute measles closures." Samoa Observer, 1 November.

https://www.samoaobserver.ws/category/article/52542 (accessed 10 December 2019).

Mayron, S. 2019h. "Ministry mum on measles but experts say communication key." Samoa Observer, 8 November.

https://www.samoaobserver.ws/category/article/52907 (accessed 5 December 2019).

Mayron, S. 2019i. "National Emergency Operation Centre mans measles response." Samoa Observer, 19 November.

https://www.samoaobserver.ws/category/samoa/53483 (accessed 6 December 2019).

Mayron, S. 2020. "Hospital's fatal shortfalls exposed." Samoa Observer, 5 February. https://www.samoaobserver.ws/category/samoa/57569 (accessed 2 March 2020).

McFarland, J. W., Mansoor, O.D., and Yang, B. 2003. "Accelerated Measles Control in the Western Pacific Region." Journal of Infectious Disease, (187) s.11, 246 - 251.

Medical Record. 1911. Medical Record, vol. 80 (10), p.482. 
Meyer, J. 2019a. "Measles outbreak in Auckland has Pacific nations on alert." Radio New Zealand, 9 September.

https://www.rnz.co.nz/international/pacific-news/398410/viral-measles-outbreak-inauckland-has-pacific-nations-on-alert (accessed 3 December 2019).

Meyer, Jenny. 2019b. "Measles outbreak: South Auckland Pacific Pre Schools worst hit." Radio New Zealand, 2 October.

https://www.rnz.co.nz/international/pacific-news/400129/measles-outbreak-southauckland-pacific-pre-schoolers-worst-hit (accessed 3 December 2019).

Meyer, J. 2019c. "Samoa measles epidemic: Immunologist furious at New Zealand." Stuff.co.nz, 1 November.

https://www.stuff.co.nz/national/health/117079712/samoa-measles-epidemicimmunologist-furious-at-new-zealand (accessed 25 November 2019).

Ministry of Health. 2019. Samoa Ministry of Health - Measles Epidemic Update 4. October 30, 2019. https://www.health.gov.ws/wp-content/uploads/2019/10/final-measels-release-43010 19.pdf (accessed 25 November 2019).

$\mathrm{MOH}$ and SBS. 2015. 2014 Samoa Demographic Health Survey. https://www.sbs.gov.ws/digi/Samoa\%20DHS\%202014.pdf (accessed 10 March 2020).

Morrah, M. 2018. "First court hearing for nurse charged over Samoa vaccine deaths." Newshub, 14 August.

https://www.newshub.co.nz/home/world/2018/08/first-court-hearing-for-nurse-chargedover-samoa-vaccine-deaths.html (accessed 5 November 2019).

New Zealand Health Act 1920 (11 GEO v 1920 No 45)

New Zealand Herald.1893. "Samoan news." New Zealand Herald, vol. 30, issue 9350, 6 November.

New Zealand Ministry of Health. 2018. "Ministry of Health statement on the investigation into MMR vaccine safety in Samoa." July 12, 2018.

https://www.health.govt.nz/news-media/news-items/ministry-health-statementinvestigation-mmr-vaccine-safety-samoa (accessed 5 November 2019).

New Zealand Ministry of Health. 2019, 2020 National and DHB immunisation data https://www.health.govt.nz/our-work/preventative-healthwellness/immunisation/immunisation-coverage/national-and-dhb-immunisation-data

NHS. 2018. Annual Report Financial Year 2017/2018. Samoa National Health Service

NHS Amendment Bill. 2018, Available at https://www.palemene.ws/wp-content/uploads/NHSAmendment-Bill-2018-Eng.pdf (Accessed 24 July 2020).

Northern Advocate. 1936. "Whooping cough and measles." Northern Advocate, 14 August.

Police v Tauvale, WSSC 43 (2019).

Press. 1938. "A suspected case of measles abroad." Press, vol.74, issue 22453, 14 July.

Razzaki, J. A., and Kellermann, A.L. 2002. "Emergency Medical Care in developing countries." Bulletin of the World Health Organization, 80 (11): 900-905.

https://www.scielosp.org/pdf/bwho/2002.v80n11/900-905/en (accessed 22 February 2020).

RNZ.2019. "Private Clinic in Samoa probed for unauthorized measles vaccinations." Radio New Zealand. 25 November, 2019.

https://www.rnz.co.nz/international/pacific-news/404029/private-clinic-in-samoa-probedfor-unauthorised-measles-vaccination (accessed 5 December 2019).

Samoa Act 1921 (12 GEO V 1921 No 16)

Sanerivi, S.S.2019. "Ministry of Health silent on vaccine shortage reports." Samoa Observer, 4 November.

https://www.samoaobserver.ws/category/article/52762 (accessed 5 December 2019).

Santayana, G. 1905. The Life of Reason: Reason in Common Sense. Scribner's.

SBS. 2013. Samoa Statistical Abstract 2011.

https://www.sbs.gov.ws/digi/2011-\%20Samoa\%20Bureau\%20of\%20Statistics\%20 (SBS) \%20Statistical\%20Abstract.pdf (accessed 10 December 2019). 
SBS. 2016. Samoa Socio-Economic Atlas 2016.

https://www.sbs.gov.ws/images/sbsdocuments/Population and Demography/SOCIO ECO NOMIC Atlas2016.pdf (accessed 10 December 2019).

Schoeffel, P. 1984. "Dilemmas of Modernization in Primary Health Care in Western Samoa." Social Science and Medicine, 19(3): 209-216. DOI: 10.1016/0277-9536(84)90212-0.

Schoeffel, P. 2016. Revitalization of Samoa's Village Women's Committee for Public Health Promotion. Unpublished briefing paper prepared for WHO.

Sonder G. and Ryan D. 2020. Health Sector Response to the 2019 Measles Outbreaks Final (including response to participant feedback) 1 July 2020. New Zealand Ministry of Health https://www.health.govt.nz/system/files/documents/publications/health sector response to the 2019 measles outbreaks 1 july 2020.pdf (Accessed on September 18 2020)

Stein-Zamir, C., Abramson, N., Edelstein, N., Shoob, H., Zentner, G., and Zimmerman, D.R. 2019. "Community - Oriented Epidemic Preparedness and Response to the Jerusalem 2018-2019 Measles Epidemic." American Journal of Public Health, 109(12): 1714-1716. https://ajph.aphapublications.org/doi/10.2105/AJPH.2019.305343 (accessed 16 December 2019).

Tauaa, S. and Schoeffel, P. 2019. "Town as village: Urbanization, Governance and Neotraditionalism in Samoa." Journal of Samoan Studies, 9: 7-20. https://journal.samoanstudies.ws/storage/2020/02/JSS Vol9 2019-Town as VillageUrbanisation Governance and Neotraditionalism in Samoa.pdf (accessed 24 July 2020).

Tautua-Fanene, D. 2018. "Women fear vaccine deaths." Samoa Observer. 14 July. https://www.samoaobserver.ws/category/samoa/31142 (accessed 1 May 2020).

Thomas, P. 1986. "Dimensions of Diffusion: Primary health care in Western Samoa." PhD thesis, Canberra, Australian National University.

Thomas, P. 2001. "Empowering community health: Women in Samoa." Pp. 532-539 in Oxford Handbook of Public Health Practice, eds D. Pencheon, C. Guest, D. Melzer and J. Muir Gray. Oxford University Press, Oxford.

Tomkins, S. M. 1992. "The Influenza Epidemic of 1918-1919 in Western Samoa." Journal of Pacific History, 27(2): 181-197. http://www.jstor.org/stable/25169127 (accessed 15 March 2020).

Tupufia - Ah Tong, L. T. 2019a. "Son dies; family lives in fear." Samoa Observer, 20 November. https://www.samoaobserver.ws/category/samoa/53536 (accessed 10 December 2019).

Tupufia - Ah Tong, L. T. 2019b. "P.M. deflects measles blame, points to parents instead." Samoa Observer, 6 December. https://www.samoaobserver.ws/category/samoa/54386 (accessed 10 December 2019).

Tupufia - Ah Tong, L. T. 2019c. "P.M. rejects call for measles inquiry." Samoa Observer, 7 December. https://www.samoaobserver.ws/category/article/54414 (accessed 12 December 2019).

Ulutoa, J. 2019. "Street talk Public urge Ministry of Health to dispatch vaccination teams to villages." Samoa Observer, 11 November. https://www.samoaobserver.ws/category/article/52842 (accessed 12 December 2019).

Vai, M. 2019. "Anti-Vaxxer Edwin Tamasese Released on Bail." Samoa Global News, 11 December. https://samoaglobalnews.com/anti-vaxxer-edwin-tamasese-released-on-bail/ (accessed 20 January 2020).

Wilson, S. 2019. "Patients turned away; vaccination plan unfinalised." Samoa Observer, November 19. https://www.samoaobserver.ws/category/article/53529 (accessed 10 December 2019).

World Health Organisation. 2019a. "Data for 2014-2018." http://www.who.int/immunization/monitoring surveillance/routine/reporting/en/ laccessed 10 January 2020).

World Health Organisation. 2019b. "Measles." December 5, 2019. https://www.who.int/news-room/fact-sheets/detail/measles (accessed 10 January 2020). 
World Health Organisation. (2020). "Immunization, Vaccines and Biologicals Data, statistics and graphics."

https://www.who.int/immunization/monitoring surveillance/data/en/ (accessed 10

February 2020).

World Health Organization and UNICEF. 2018. "Pacific statement on the deaths of two children in Samoa after MMR vaccine." July 11, 2018.

https://www.who.int/westernpacific/about/how-we-work/pacific-support/news/detail/11-

07-2018-world-health-organization-and-unicef-pacific-statement-on-the-deaths-of-two-

children-in-samoa-after-mmr-vaccine (accessed 15 November 2019). 